\title{
Eleventh British Universities Siberian Studies Seminar: 11-15 September 2006, Vladivostok
}

\author{
JOSEPH LONG, UNIVERSITY OF ABERDEEN
}

$\mathrm{T}$ he 11th British Universities Siberian Studies Seminar (BUSSS) took place from the 11th to the 15th of September 2006 in Vladivostok and was hosted by the Pacific Institute of Geography of the Far Eastern Section of the Russian Academy of Science. Entitled "Siberia and the Russian Far East: Past, Present and Future," the meeting marked the 25th anniversary of BUSSS and was attended by around 40 participants from all over the world

\section{Monday, 11 September}

The conference was formally opened on Monday morning by Academician Petr Baklanov of the Pacific Institute of Geography in Vladivostok and Dr. John Sallnow of the University of Plymouth. Proceedings began with Dr. Alan Wood of Lancaster University, the founder of the seminar, reflecting on 25 years of BUSSS from its modest beginnings as a meeting of 12 British scholars in 1981 to the international conference it has become today. As recognition of Dr. Wood's contribution to BUSSS, the organizing committee presented him with a diploma acknowledging his efforts over the years.

FIRST PANEL: The Resources of Siberia and the Russian Far East under Conditions of Globalization

Chair: Professor Victor Mote, University of Houston, Texas

Professor Boris Preobrazhensky of the Pacific Institute of Geography in Vladivostok started the presentations with a paper entitled "Underwater Estate Monitoring and Cadastre." Professor Takeshi Murota of 
Doshisha University, Kyoto, Japan then gave a paper co-authored by Tamara Khantashkeeva of the Institute of Geography in Moscow, "Six Types of Spatial Transformation in Natural Resource Development in East Siberia and the Far East." Nikolai Kazakov of the Wildlife Conservation Society of Vladivostok followed, speaking on "Tiger Friendly Certification: Linking the Economic Development of Rural Areas with Conservation."

Dr. Svetlana Kozhenkova of the Pacific Institute of Geography turned the focus back toward marine landscapes with a paper entitled "How Tourism Development in Primorskii Krai Can Influence Marine Ecosystems," and Aleksandr Levintov of the Academy of the National Economy, Moscow, closed with a paper that summarized resource use across the region entitled "Models of Development and Use of Territories and Resources."

\section{Tuesday, 12 September}

SECOND PANEL: "History and Historiography"

Chair: Dr. Alan Wood, Lancaster University

Professor Wakio Fujimoto of Osaka University of Economics and Law in Japan started off day two with a paper entitled, "Japanese Society in the Russian Far East after the Russian Revolution." In his presentation, "Human Impact on the Environment in Prehistoric and Early Historic Times in the Russian Far East," Dr. Yaroslav Kuzmin, of the Pacific Institute of Geography, demonstrated through archaeological evidence the development of early horticulture and agriculture in Primorye between 5000 and 2300 BCE. Julia Ulyannikova of Melbourne University presented on "Katorga as an Institution in Transition: Reform of the Russian Hard Labour and Penitentiary Discourse," and Willard Sunderland of the University of Cincinnati spoke on "Baron Ungern's Eurasia." Dr. Vladimir Sokolov of the Arsenev Museum then joined the meeting to talk a little about the history of Primorskii Krai as a prelude to a tour of the museum.

The history panel was resumed when the Russian penal system was again addressed by Andrew Gentes of the University of Queensland, Australia. Gentes's paper was entitled "The Sakhalin Penal Colony as Cause Célèbre." Yevgeny Suvorov of the Russian Geographic Society, Ternei, closed with a paper named "To the History of 'Tartaria' and the Tatar Strait." 


\section{Wednesday, 13 September}

THIRD PANEL: "Economics and Regional Economic Policy"

Chair: Academician Petr Baklanov, Pacific Institute of Geography, Vladivostok Professor Alexander Alekseyev of Moscow State University began this panel by summarizing stages in Siberia's economic development in a paper titled "Changes in the Functions of Economic Regions in Siberia and the Far East." Professor Norio Horie of the Centre for Far Eastern Studies, University of Toyama, Japan, spoke on "Russia's Foreign Labour Management from Northeast Asia's Perspective," and Dr. Vladimir Karakin of the Pacific Institute of Geography spoke on "Zones of Economic Activity in the Russian Far East (South Portion)." Professor Chang Bin, director of the Institute of Russian Central Asian and East European Studies in Beijing, spoke on "Research on the Border Trade between China's Heilongjiang Province and Russia," and Elizabeth Engebretson of Macalester College, United States, gave an insightful paper, "Personal Plots: Key to Survival and Part of Culture," on subsistence activities in the Republic of Buriatiia. Evgeniy Zharikov of Far Eastern State University highlighted a decrease in local industrial growth in a presentation on "Problems of Industrial Development in Primorskii Krai."

FOURTH PANEL: "Geopolitical Problems in the Development of Siberia and the Russian Far East"

Chair: Dr. John Sallnow, University of Plymouth

Academician Petr Baklanov of the Pacific Institute of Geography spoke on "The Contemporary Geopolitical Position of the Russian Far East," while Dr. Vladimir Bocharnikov's presentation, "The Russian Far East: A Regional Approach to the Application of New Principles of Ecological and Cultural Studies," co-authored by Professor Dmitriy Sevastyanov of Saint-Petersburg State University, prompted an interesting discussion about where the Russian Far East fits into 'area studies'.

Professor Grigory Olekh of Novosibirsk State Academy of Water Transport Engineering, Novosibirsk, turned to the theme of controlling the flow of illegal goods into Siberian markets in his paper "The Gusinobrodskaia Anomaly as a Symptom of the Degradation of Siberian Provincial Authorities." Dmitrii Sidorov of California State University, Long Beach, talking on "The East in Contemporary Russian Orthodox Geopolitics," showed the ambiguous nature of the Russian east in "third Rome' discourses. Gerald Mikkelson, of the University of Kansas, further added cultural perspective to the place of Siberia in Russian identity in his paper on "Valentin Rasputin at 70." 


\section{FIFTH PANEL: "Population and Resettlement"}

Chair: Professor Alexander Alekseyev, Moscow State University

Dr. John Sallnow of the University of Plymouth used Russian governmental statistics to underline what he suggested is a population crisis in Siberia in his paper, "The Population of Siberia and the Russian Far East 1989-2002." A paper by Professor Sadayoshi Ohtsu of Osaka Sangyo University, "Cross Border Labour Migration in the North East Asia: Some Specific Features Compared with South East Asian Case," highlighted some problems of using existing models of migration policies in the region. Alexey Lankin of the Pacific Institute of Geography spoke on "The Geographical Correction of Human Capital in the Russian Far East" and highlighted the symbolic factor of the 'Asia-Europe' border shaping attitudes to migration.

\section{Thursday, 14 September}

\section{SIXTH PANEL: "Culture, Ethnography and Folklore"}

Chair: Dr. Albina Girfanova, Saint-Petersburg

Professor Maria Lebedko of Far Eastern National University, Russia, started the final day with "The Other Side of Russia: The Image of the Russian Far East in Travelers' Books." Professor Birgitta Ingemanson of Washington State University, in a talk entitled "Between the Two Bays: A Vladivostok Portrait, 1894-1930," painted a picture of Vladivostok in the tumultuous years of the early twentieth century. Nellie Miz, of the Arsenev Museum, placed this personal account into a wider context of a cosmopolitan Vladivostok in her paper on the "English-Speaking Population of Vladivostok." Vasiliy Solkin, environmentalist and editor of the local publication Zov Taigi, then showed a film about local conservation projects aimed at protecting the Amur tiger.

\section{SEVENTH PANEL: "Indigenous and Minority Populations"}

Chair: Professor Anatoly Kuznetsov, Far Eastern State University, Vladivostok In Albina Girfanova's presentation, “V. K. Arsenev as a Researcher of the 'Orochi' and Their Language (Tentative Approaches to his RussianOroch Dictionary)," Girfanova noted the importance of Arsenev's work on languages of the indigenous peoples of the Far East. In a paper titled "Indigenous Peoples of the Far East and Oriental Siberia in S. M. Shirokogoroff," Professor Anatoly Kuznetsov of Vladivostok's Far Eastern State University proposed that Shirokogoroff's theoretical approaches to 'ethnos' are still of relevance to social anthropology. 
EIGHTH PANEL: "The Position of Siberia and the Far East in the World Ecosystem"

Chair: Professor Boris Preobrazhensky, Pacific Institute of Geography, Vladivostok

In the final panel of the conference, Professor Manfred Frühauf of Martin-Luther-University, Halle-Wittenberg, Germany, spoke on "Ecological Consequences of Steppe Conversion to Arable Land in West Siberia and Kazakhstan," noting the widespread soil degradation and increased carbon dioxide emission from the soil that resulted from the Virgin Lands campaigns of the 1950s and 1960s. In the last paper, Professor Viktor Rudsky of Smolensk University of the Humanities urged a balance between economic development and ecological protection in the region in his paper, "Natural Resources Potential of Siberia: Study, Use and Protection."

\section{Plenary Meeting}

Chairs: Academician Baklanov and Dr. Sallnow

At the plenary meeting Professor Alekseyev extended an invitation to host the next meeting of BUSSS at Moscow State University, which was accepted by participants. Dmitri Sidorov suggested that the presence of students and postgraduates at the conference should be encouraged and the organizing committee for Moscow hopes to make some money available to assist student presenters to come to the conference next time. The meeting was deemed to be an overall success before being formally closed by Academician Baklanov and Dr. Sallnow.

\section{Friday, 15 September}

On the last day a boat trip through the harbor, known as Vladivostok's 'Golden Horn', and the islands to the south of the peninsula was organized. As the boat sailed home, the atmosphere of fun, underpinned by some interesting talks about our region and ways to take the field forward, summed up the collegiate nature of the conference.

Congratulations to the organizing committee. Thanks to Galina Dimova and her team, airport transfers, excursions, and panels ran smoothly, while the work of Academician Baklanov and Dr. Sallnow ensured that papers of a strongly varied nature but high quality were presented. 